\title{
Woman Struggle in Paulo Coelho's the SPY
}

\author{
EKA NOVIYANTI ${ }^{1}$, AMrin SARAgIH ${ }^{2}$, MUHAMMAd NATSIR ${ }^{3}$ \\ ${ }^{123}$ UNIVERSITAS NEGERI MEDAN
}

\begin{abstract}
This study discussed woman struggle in Paulo Coelho's The Spy. The objectives were to find out the kinds of woman's struggle in Novel The Spy, the ways the main character struggles to fulfill her needs, and the reasons why the main character struggle in the way she did. This study used descriptive qualitative method. This study used Maslow (1987) theory to analyze the kinds of woman's struggle and the ways the main character struggles to fulfill her needs that she had faced and elaborated the reasons by using theory of ambition. The result of this study can be concluded in some aspects. First, the kinds of woman's struggle found in Novel The Spy in fulfilling the human needs, namely: Struggle for Survival, Struggle to Reach the Dream, Struggle for Love \& Relationship, Struggle in Getting A Good Reputation and Struggle to be Independent Woman. Second, the ways the main character struggles to fulfilling her needs are exchange sex with favors and money, making relations with men from the higher classes and to be a Spy. Third, the reasons why the main character struggle are because of her ambition to become a Free Woman and influenced by author's background.
\end{abstract}

Keywords: Feminism, Struggle, Human Needs, Novel 


\section{INTRODUCTION}

Literature as a media that can help inform people to understand feminist thinking and feminist politics that are written in range of style and formats (Hooks, 2015). Literature has a function to designate fictional or imaginative writings (Abrams, 2012). As fictional writing, literature can be found in literary work, such as a novel. Woman struggle has been widely discussed lately, based on data in scholar.google.com, there are about 44 research discussed about woman struggle in 2019-2020 which is wrapped in many interesting literary works in the world. As examples, in 2019 the research about woman struggle discussed with title The Struggle of Woman Reflected in Cigarette Girl Novel by Ratih Kumala Mary written by M Susilo. Then, the research about woman struggle in 2020, there are Woman Struggle Experienced by Patty Day In Gillian Flynn's "Dark Places"(2009): A Marxist Feminist Theory written by AW Rustamaji and Y Prastiwi, also Woman social struggle in Ella Wheeler Wilcox's' Solitude' written by MR Nata.

Wollstone (2004) in her book A Vindication of the Rights of Woman believes that women should be given the equal rights and status as they are not only a commodity that is to be traded in the marriage instead a significant part of the society. Women's struggle is carried out as a form of emancipation, where the emancipation as a process contains ongoing criticism of existing injustices because social claims develop in response to changes in social conditions. The idea of emancipation also can be modified during the process of its enforcement under the influence of changing social contexts (Uhde, 2016). In this situation, women's emancipation is influenced by the conditions experienced by them, namely gender and social injustice, which are the history or background of economic and cultural inequality in a region.

Related to woman's struggle in patriarchal society where the system of society or government controlled by men, Millet (2016) said that women have a situation where they shape their awareness as women both in the community and at home, to demand their equality with men. The resistance is the emancipation of women in voicing their rights and trying to get what they are aiming for. So, feminism is an awareness of women who are under man's domination in many aspects and a set of actions to resist it (Bhasin and Khan, 1995). In this case, feminism includes resistance, struggle, and emancipation. Woman's struggle leads to several theories of feminism that we can find the story through literary works in novels, prose, and drama. As a part of feminism, woman's struggle also is seen as the real action of a woman who wants equality in their lives and to achieve their dreams as a real woman.

Many stories of woman's struggle can we found from different novel. The obstacles that woman go through to fight for their rights are often exciting things to discuss. Women in the world began to demand emancipation in the 18th century. The Spy is a novel written by Paulo Coelho in 2016. Paulo Coelho's novel, written with a background story in the First World War. Mata Hari as the main character in this novel gives its impression, where it is in the position of woman who asserts her rights in the era of the First World War. Desires of Mata Hari is an 
ambition related to the actions she takes next in the novel.

There are some reasons why the researcher is interested in analyzing this topic. The first, in the previous study titled Women's Oppression Reflected In Paulo Coelho's "The Spy" Novel (2016): A Feminist Perspective by Dyan Nur Ayni in 2018, she suggested to the reader in the future research to analyze Mata Hari's desire in her dreams. In her research, she only discussed oppression that reflected in the main character with theory feminist perspective. The second reason, this novel was using the first-person perspective, and also the novel tells about a woman who is free, broad-minded and trying to fight for her dreams. The action of Mata Hari in facing any pressure in her life inspired researchers as a fellow woman to elevate the struggle of woman that should be valued. The rise of cases of oppression of woman lately brought this research to inspire readers for the struggle and courage of Mata Hari in an era that is still difficult to speak out. At the same time, Mata Hari at that time was brave enough to fight for her role as a woman.

So, this research interested to find out the kinds of Mata Hari's struggle in Novel The Spy, to elaborate on the ways Mata Hari struggle to fulfil her needs, and also to give the reason why Mata Hari struggle in the way she did.

\section{Feminism Theory}

Feminism is a women movement that happens almost all over the world. Hooks (2015) said that feminism is a movement that aims to end sexism, sexist exploitation and oppression. Nevertheless, feminism does not always talk about it. According to Ratna (2010), feminism is a movement of women to demand equal rights to men, in the social, political, and economic, as well as the cultural sector in general.

So based on the above theory, As said by Ratna (2010) we can conclude that feminism also discusses the limited struggle of women in pursuing their dreams both in the fields of art, politics and equality with men in economic terms, means that women who aim to fight for the rights of women as a social class. It is related with feminism in Novel The Spy where equality in economic, social and politic not obtained by women.

\section{Woman Struggle}

According to Marsam (2000), the struggle comes from the word that means a fight for survival or independence of the state. The struggle in this research effort is mean as a woman to defend the rights and dignity of women who oppressed due to the arbitrary injustice of considerable cultural flourishing in society.

Hooks (2015) said that a few of these women defied convention and worked outside the home performing tasks way below their educational skills and facing resistance from husbands and family. It was known that women nowadays still struggle in living with life under patriarchy system. Women struggle occurs as the effect of gender inequality. Men give unequal treatment or discrimination for women. It occurs because there are women discrimination to get access to the 
same opportunities and treatments as men in their society and family.

\section{Ambition}

Quaglia \& Cobb (1996) said that ambitions represent the perception that an activity is essential as a means to future goals. It reflects individuals' perceptions that it is both possible and desirable to think in future terms and to plan for the future. According to Timothy A. Judge \& John D (2012), ambition is the generalized striving for success, attainment, and accomplishment. It involves persistence and generality that we don't expect and the ambition ceases to exist once a certain level of attainment achieved. Ambition generally has been taken to striving for position and wealth, not to indicate strivings for general wellbeing, and also socio-emotional acceptance. Based on Timothy's statement means that ambition means that ambition can interpreted as a desire possessed by someone who is behind the struggle that she is doing.

\section{Hierarchy of Human Needs}

In this research, the theory of human needs used as the leading theory for analyzing the research. Rohrberger \& Woods (1971) said there are five approaches can implemented in the study of literature; one of them is psychological approach. Theory hierarchy of human needs is one of the psychological approach that used to interpret literary work (Wellek \& Waren, 1956) so that this theory used to interpret the woman's struggles did by Mata Hari in the novel.

Maslow (1987) said that people are motivated to achieve particular needs and that some needs take precedence over others. There is five hierarchy of human needs based on Maslow's theory:

1. The physiological needs (food, water, sleep, sex, and shelter)

2. The safety needs (security and safety)

3. The love and Belonging needs ( intimate relationship, family, friends)

4. The esteem needs (achievement, recognition, respect)

5. The need for self-actualization (achieving one's full potential, creativity, talent)

In investigate what struggles Mata Hari did in the novel, the theory applied in this research. Through Maslow's theory, the needs identified is what drives Mata Hari to fight for her rights as a woman. This Theory of Human Needs has five hierarchies of needs that found in a person. Mata Hari as the main character in Novel The Spy did action based on her ambition to meet her needs. As primary data, we can see from the quote sentence in below:

"I don't know if the future will remember me, but if it does, may it never see me as a victim but as someone who moved forward with courage, fearlessly paying the price she had to pay." (Coelho, pg.15)

From the above quote, we can see that Mata Hari wants her to remember with respect by others for her life's struggle, which she conveyed through her last letter. This shows that Esteem Needs are reflected by Mata Hari as a reflection of her evaluation. 


\section{RESEARCH METHODOLOGY}

This research adopted a qualitative approach. Vanderstoep and Johnston (2009) said that qualitative research focuses on the meanings of experiences by exploring how people define, describe, and metaphorically make sense of these experiences. According to Vanderstoep and Johnston (2009), qualitative research use inductive analysis of "text". The researcher prefers to use this method because as said by Vanderstoep and Johnston (2009), there are five different qualitative research methodologies, such as ethnography, phenomenology, case study, textual analysis, and applied research. Based on the above statement, this research can apply with textual analysis as a part of qualitative method.

The source of data for this research is the novel The Spy written by Paulo Coelho, published by Alfred A. Knopf in 2016. This novel has 208 pages. This novel purchased through an online platform. In this research, the researcher analyzed the novel from the sentences in the form of act, conversation, and point of view of Mata Hari. The secondary data taken from websites, journals, articles, the book of literature and other sources which relate to this research.

According to Vanderstoep and Johnston (2009) in collect the data, qualitative studies use ethnography (saw the meaning from the perspective of the culture studied), phenomenology (focuses on how people experience a particular phenomenon; that is, the sine qua non of an experience), case study (a description and interpretation of the case from site and documents), textual analysis (The researcher is the interpreter of the selected text or texts), and applied research (Individual, group, or organization). So, this research used textual analysis where the data was text or conversation and researcher as an interpreter (Vanderstoep and Johnston, 2009). In collecting data, the researcher did some procedures as follows:

1. Reading the novel repeatedly 4 times and carefully. In reading the novel, this research used a hardcopy of the novel.

2. Marking the sentences when third reading used a highlighter, as the quotation that indeed illustrated the needs that want to fulfill by Mata Hari in the novel.

3. Collecting the quotation as a data and move the data into a table by using Microsoft word in the computer, then giving the code of the data, letter $\mathrm{D}$ as the number of data, and $\mathrm{P}$ as the pages in novel, following the letter A, B, C in line if the data comes from the same pages. Example: D1,P12, it means that it is the first data in page 12.

4. Collecting some related information from articles, the internet, or e-books such as a book about author's biography and review about the novel The Spy in internet and article.

In analyzing data, the researcher used a descriptive qualitative method to analyze the women's struggle. Vanderstoep and Johnston (2009) state that qualitative research has a purpose of descriptive. Since people's interpretation is the main element of qualitative research, its products are 
in the form of description. The technique of analyzing data for this research consists of:

1) Identifying the sentences that reflected the struggle of Mata Hari with finding out the sentences that illustrated the needs that want to fulfil by Mata Hari. The sentences will take from the action, dialogue and description illustrated in the novel The Spy by Paulo Coelho in 2016.

2) Classifying the struggle based on Maslow's theory (1987) about a hierarchy of human needs, from this theory researcher will find kinds of struggle in Mata Hari's life.

3) Analyzing the realization of Mata Hari's struggle in fulfilling her needs with theory of Human Needs, that are the esteem need and the need for self-actualization.

4) Describing the reason why Mata Hari struggle to reach her dream with associating it to the theory of ambition \& human needs.

\section{FINDINGS and DISCUSSIONS}

\section{Kinds of Woman's Struggle in Novel The Spy}

There are five kinds of woman struggle found in the novel The Spy. They are Struggle for Survival, Struggle to Reach The Dream, Struggle for Love \& Relationship, Struggle in Getting A Good Reputation, and Struggle to be Independent Woman.

1. Struggle for Survival

"Yes, I turned this gossip into "secrets," because I wanted money and power." (D2, $\mathrm{P} 13 \mathrm{~A})$

The data above explained that this sentence illustrated the physiological needs that occur in Mata Hari in the novel The Spy, the sentence I wanted money and power illustrated physiological needs. Mata Hari used the gossip circulating among the top as confidential information that she can provide as a result of her work being a spy.

2. Struggle to Reach The Dream

"With a dictionary in hand, I approached a young woman who must have been more or less my age and asked, with great difficulty, how to find the hotel the consul had reserved for me." (D10, P46).

From the data above, Mata Hari went to the country of France and tried to find information on hotels in the area. She tried to meet safety needs by using a dictionary to communicate with people there. She did it to realize her dream of becoming a famous dancer back in the city. When Mata Hari tries to meet those needs, those needs encourage Mata Hari to strive to achieve her dreams. The purpose of meeting with the consul was none other than 
to raise her career back and become a free woman.

3. Struggle for Love \& Relationship

"I crossed glances with my one true love, a Russian who had been blinded by the mustard gas used so indiscriminately in this war and for whom I was willing to do anything." (D32, P136A)

From the data above, Mata Hari, who could not be trusted with love before, returned to find someone who could say as her true love. This love and belonging needs show us that this need is to make someone do anything for the sake of the closest person.

4. Struggle in Getting A Good Reputation

"Here they no longer treat you with the respect you deserve, so maybe you would like to perform in a place where they know you as the greatest dancer of the century? I am talking about Berlin, the city where I'm from. It was a tempting proposition." (D24, P93).

When the man said that Mata Hari was no longer treated with the respect in the country she was living in, then the offer of the man to let Mata Hari want to come to work in Berlin, was the path she took so that respect for her return. It means that esteem needs to encourage Mata Hari to struggle to get a good reputation for herself.

5. Struggle to be Independent Woman

"The crimes I did commit, I escaped, the greatest of which was being an emancipated and independent woman in a world ruled by men." (D1, P12).

The data above is self-actualization which explained in the previous sub-chapter. The sentence said by Mata Hari is evidence of Mata Hari's struggle to become an independent woman. The desire of Mata Hari to actualize herself also encourages Mata Hari to struggle. One of the characteristics of self-actualizing people is their independence of physical and social environment (Maslow, 1987).

\section{The Way Main Character Struggle to Fulfilling Her Needs}

The realization of the Mata Hari's struggle found in three ways, namely Exchange sex with favors and money, Making relations with men from the higher classes, and To be a Spy.

\section{The Reasons Main Character Struggle in the Way She Did}

There are the reasons for the struggle of Mata Hari. They are Because of her ambition become a free woman and Author's background.

After analyzing the struggle did by Mata Hari in the novel The Spy using Maslow's theory (1987), it can be concluded several points from the analysis. 
The first is, in the novel The Spy found the five hierarchies of needs based on Maslow's theory (1987), namely physiological needs, safety needs, love and belonging needs, esteems needs, and selfactualization needs that sought to be fulfilled by Mata Hari and encouraged herself to struggle. The five types of struggles did by Mata Hari based on the five hierarchies are struggle for survival, struggle to reach the dream, struggle for love \& relationship, struggle in getting a good reputation and also struggle to be an independent woman. The most struggle done by Mata Hari as the main character is the struggle to reach her dreams. That happened because, during the First World War, it was difficult for women in the world to be free to do anything even to come up with ideas or talk like men at that time.

As said by de Beauvoir (2011), the position of women makes them an object for men, especially with the situation or status of women who are married and become a wife. So it is limited to Mata Hari to get her rights. When viewed in terms of feminism, Mata Hari made a movement to get equal rights in terms of expressing opinions, making decisions, establishing relationships with all people, and appearing in public at that time. That is in line with what is said by Ratna (2010) that feminism is a women's movement to get equal rights with men in many aspects. The struggle carried out by Mata Hari is a form of woman struggle that occurred in the era of World War I, such as travelling a great deal such as Mata Hari was something unusual.

The findings in this research show the differences in previous studies that also use Maslow's theory; its only found three needs that described woman struggle in the novel. However, in this research, it was found the five hierarchies of needs that showed the kinds of struggles conducted by Mata Hari in the novel The Spy. It influenced by several aspects such as the differences in the characters described by the authors in Indonesian novels and International novels, and also the description of women in each novel as the main character. Then, this finding is in line with previous research that also examined the novel The Spy, where in previous studies found oppression experienced by Mata Hari namely in terms of women's rights and women's role. This related to the findings of this research, in which Mata Hari struggle for her life, reputation, and freedom as part of women's right and also strives to achieve her dreams even though she has taken on the role of wife, mother and career woman that included in the women's role.

The second is, Mata Hari struggles to reach her dreams in her way, namely exchange sex with favor \& money, making relations with men who come from the higher class and to be a spy. These three ways she did by looking at the possible situations that could be exploited by Mata Hari. Suppose those ways applied in the current era will indeed have pros and cons. The struggle of women in the modern era is more open and can be done in ways that are legal and sportive, such as through publishing books, plunging into politics and other emancipations. In contrast to the struggle of women during the First World War, where sexual exploitation of women often carried out to provide a background for each woman for her life, including Mata Hari, who used sex and influential people at that time to reach her dreams. 
The needs fulfilled in carrying out these ways are esteem needs and self-actualization needs, where Maslow (1987) said that other needs would arise if the previous needs she feels fulfilled. Mata Hari exchanged sex with something that could help her become a famous dancer again and be able to live freely in Paris as she wishes. So these three ways are mutually sustainable and deliver them from one way to the next.

Finally, the reason why Mata Hari struggled to reach her dream as the way she had done was because of her ambition to become a free woman. Ambition will encourage someone to do something that can realize these ambitions. Mata Hari who likes adventure makes her want freedom. This ambition can bring Mata Hari to both positive and negative things. Ambition has generally been taken to reflect striving for position and wealth, and not to indicate strivings for general wellbeing and socioemotional acceptance (Timothy A. Judge \& John D, 2012). Same with Mata Hari's ambition which is done for freedom over her and does not want to be considered the same as other women.

The only need that drives this reason is self-actualization, where this need is the top level in the hierarchy of needs. Maslow (1987) explains the characteristics of self-actualizing people are independent of culture, spontaneity, simplicity, and naturalness. Paulo Coelho as the author, described Mata Hari as a spontaneous woman. Mata Hari being an Asian dancer is a form of spontaneity and being naked in public is a sign that she is the independence of culture.

Mata Hari's experience was no more significant than her desire to be free as a woman. Besides that, the reason why she did the ways that she did to reach her dream was also not separated from Paulo Coelho as the author of the novel The Spy. The story of Mata Hari and her life is a true story that was rewritten by Paulo Coelho with relevant fictional additions. Living Mata Hari ended with the execution she received because she accused of being a double spy, besides that Mata Mata's desire was only to be a free woman as he thought, but there was no substantial evidence for her defence. Paulo Coelho portrayed the main female characters in some of his novels published before The Spy novel almost similar, as in his novel entitled Eleven Minutes published in 2003, the main character named Maria also portrayed as a beautiful, smart woman, who fights for her life in a way become a prostitute. Then Paulo Coelho's background who lived in France and Brazil inspired him with the lives and women who lived there.

\section{CONCLUSIONS AND SUGGESTIONS}

The following are can be concluded from this research after analyzing the data based on the theoretical basis used. It was concluded that in the novel The Spy there are five hierarchies of human needs that are trying to be fulfilled by Mata Hari namely physiological needs, safety needs, love and belonging needs, esteems needs, and the need for self-actualization.

In fulfilling the five hierarchies of human needs, five types of women's struggle found namely struggle for survival, struggle to reach the dreams, struggle for love \& relationship, struggle in getting a good reputation, and struggle to be an independent woman. 
The ways by Mata Hari as the main character to fulfilling her needs were to exchange sex with favor \& money, making relations with men who come from the upper class and to be a spy. The three ways that Mata Hari has done related to one another.

The main reason Mata Hari carried out these struggles in the ways above is because of her ambition to become a free woman. Besides that, it also supported by another thing, namely Paulo Coelho's background, which influenced her ways of describing women as the main characters in each novel. Thus this research has been completed with the presentation of research results that have submitted. The struggle for women will continue to exist with different obstacles in each era. The high emancipation of women expected to be a motivation for women in the world, and can create a new history both in Indonesia and Internationally. Various kinds of women's struggles become their inspiration in various fields. The more human needs they have to fulfil, the more struggle they will do.

Based on the results of the analysis that has been done, then these are some suggestions as follows:

1. The Spy novel is an interesting novel to study because the facts are becoming history in the world. For readers, this research recommended not only to read about Mata Hari in this novel but can explore more information on other novels that tell the life of Mata Hari. The reader can find information on other novels in the novel The Spy.

2. This research is limited to only discussing the ways Mata Hari to reach her dreams and the reasons for her struggle. For further research, this research can be continued by discussing Mata Hari's life from the aspect of comparing stories from the perspectives of different authors and using other related theories.

3. For readers, especially women, Maslow's theory needs to be known to motivate themselves in the struggle and plan in life and also to divide between positive ambitions and ambitions that lead to negative. Emancipation and the struggle of women must continue to be made for the welfare of the lives of women.

\section{REFERENCES}

Abrams, M. H. and Geoffrey G.H. (2012). A Glossary of Literary Terms (Tenth Edition). Boston: Wadsworth, Cengage learning.

Bhasin and Khan. (1995). Persoalan Pokok Mengenai Feminisme dan Relevansinya. Jakarta: Gramedia Pustaka Utama.

Coelho, Paulo. (2016). The Spy. New York: Alfred A. Knopf.

de Beauvoir, Simone. (2011). The Second Sex (Vintage Book Edition). New York: 
Random House.

Hooks, Bell. (2015). Feminism Is for Everybody: Passionate Politics. New York: Routledge Taylor and Francis Group.

Marsam. (2000). In Siwi Dhian Anggraini Novel Ugly Karya Constance Briscoe (Kajian Feminisme). Jurnal Sapala. Surabaya: Universitas Negeri Surabaya. Maslow, A. (1987). Motivation and Personality. New York: Harper and Row.

Millet, Kate. (2016). Sexual Politics. St. Albans: Columbia University Press.

Quaglia, R. J., \& Cobb, C. D. (1996). Toward A Theory of Student Aspirations. Journal of Research in Rural Education, 12, 127-132.

Ratna. (2010). Sastra dan Cultural Studies, Representasi Fiksi dan Fakta. Yogyakarta: Pustaka Pelajar.

Rohrberger, M. \& Woods, S. (1971). Reading and Writing about Literature. New York: Random House.

Timothy A. Judge \& John D. (2012). On the Value of Aiming High: The Causes and Consequences of Ambition. Journal of Applied Psychology.

Uhde, Zuzana. (2016). From Women's Struggles to Distorted Emancipation. International Feminist Journal of Politics. Routledge. Pp.390-408

Vanderstoep, Scott W and Deidre D. Johnston.(2009). United Kingdom. Research Methods for Everyday Life. San Fransisco: Jossey Bass Wiley

Wellek, Rene and Austin Warren. (1956). Theory of Literature. New York: Harcourt, Brace and World, Inc.

Wollstonecraft, M., \& Pennell, E. R. (2004).A Vindication of the Rights of Woman. Penguin Classics. 